\title{
Yield Loss Assessment due to Turcicum Leaf Blight of Maize Caused by Exserohilum turcicum
}

\author{
K. Shankara ${ }^{1^{*}}$, R.S. Pradhan ${ }^{2}$ and S.P. Patole ${ }^{2}$ \\ ${ }^{1}$ Department of Plant Pathology, University of Agricultural Sciences, Raichur, Karnataka, India \\ ${ }^{2}$ Central Integrated Pest Management Centre, Nagpur, Maharashtra, India \\ *Corresponding author
}

A B S T R A C T

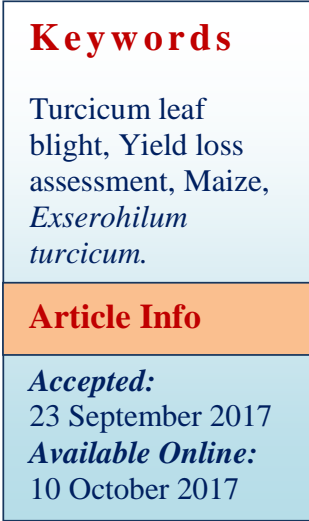

The yield losses in maize due to turcicum leaf blight were determined by using two susceptible maize cultivars viz., CM-202 and CM-219 J under artificial epiphytotic condition. The experimented was conducted with two treatments i.e., inoculated with Exserohilum turcicum pathogen culture (conidiospores) through leaf whorl inoculation starting from 25 days after sowing and protected with spray of Hexaconazole @ 0.2 per cent. The maximum grain yield loss recorded in CM-219 J (37.64 \%) followed by CM-202 (30.94\%).

\section{Introduction}

Leaf blight of maize caused by Exserohilum turcicum (Pass.) Leonard and Suggs. also known as northern corn leaf blight, is prevalent in all the major maize growing regions of peninsular India during Kharif as well as Rabi seasons, Himalayan region during Kharif season and Indogangetic plains particularly Bihar during the winter season (Lal, 1991). It is widespread disease of maize which can cause yield losses upto 70 per cent (Yashitola, 2003). Apart from yield loss, the disease causes qualitative changes in the seed resulting to decreased sugar content, germination capacity and severely infected plants are predisposed to stalk rot (Gowda et al., 1992; Cardwell et al., 1997). It reduced the grain yield of maize considerably all over India, especially in Bihar (during winter season 1989-90) and Karnataka during the rainy season for several years.

However, this disease can be controlled exclusively by exploiting genetic resistance, as both polygenic and monogenic sources adapted to tropical countries are in different maize growing regions of the world, especially in the United States of America (Brewbaker et al., 1989). As the usual extent of losses caused to grain yield have not yet precisely worked out, attempts were made to estimate the losses in grain yield due to this disease. 


\section{Materials and Methods}

The experiment was carried out with two susceptible (CM-202 and CM-219 J) cultivars sown in RCBD design with 5 replications and constituted a paired row treatment experiment. Each variety was raised in 4 rows of $5 \mathrm{~m}$ length with a spacing of $70 \mathrm{~cm} \mathrm{X} 20$ $\mathrm{cm}$. Recommended package of practices were followed to raise uniform and good crop stand except plant protection measures. Artificial epiphytotic conditions were created through leaf whorl inoculation technique to obtain uniform disease intensity.

Creation of artificial epiphytotic condition: During the course of study, the leaf whorl inoculation technique was followed using sterilized sorghum grain, as it was most effective for creating artificial epiphytotic condition in the field. Exserohilum turcicum inoculum was multiplied on sterilized whole sorghum grains, kept in $250 \mathrm{ml}$ Erlenmeyer flask after pre-soaking in water for 24 hours. Potato dextrose broth was added to these flasks before sterilization in order to provide a thin coating on sorghum grains; the flasks were autoclaved twice. The autoclaved flasks were then seeded with E. turcicum inoculum and incubated for 20 days at $28{ }^{\circ} \mathrm{C}$. The flasks were shaken once in two days to enhance the growth of the organism on the surface of grain. After obtaining enough growth, the infected sorghum grains were dried under shade and ground with equal quantity of fresh sorghum grains. Maize plants were individually inoculated by placing the powdered inoculum in the leaf whorls of 25 days old seedlings at the rate of $1.25 \mathrm{~g}$ per plant in the evening hours. A light water spray was given after inoculation to create optimum humidity for infection.

Two treatments consisted of inoculated and protected as standard check. In the inoculated treatment artificial inoculation was given three times at 5 days interval starting from $25^{\text {th }}$ day after sowing. The protected plots were kept turcicum leaf blight free by three sprays of Hexaconazole at 0.2 per cent.

The disease severity was recorded at dough stage on per cent leaf area covered by pathogen. The grain yield data was recorded at 15 per cent moisture level in protected and inoculated treatments and grain yield was recorded on hectare basis $(\mathrm{Kg} / \mathrm{ha})$. The yield differences between the protected and inoculated plots of each variety were worked out for calculating the per cent loss on potential yield. This difference was added to the yield of the protected plots and the per cent loss was computed by the following formula (Cramer, 1967).

$$
\begin{gathered}
\text { Yield difference (Yield in protected plot - } \\
\text { Yield in inoculated plot) } \\
\text { Loss }(\%)=\text {------- X } 100 \\
\text { (Yield of protected plot + Yield difference) }
\end{gathered}
$$

The disease severity was recorded on individual plant basis at dough stage.

\section{Results and Discussion}

The disease severity, grain yield and per cent grain yield loss of two varieties which are inoculated and protected were recorded (Table 1). The tabulated observation of disease severity was calculated for paired ' $t$ ' test and the data obtained was subjected for comparison between two varieties.

Among the two varieties, the severity in inoculated and protected was compared. The observed ' $t$ ' values were compared with table ' $t$ ' value. Both the varieties exhibited significant response against the disease severity. The severity was maximum $(89.4 \%)$ in inoculated treatment on variety CM-219 J and it was 6.5 per cent in protected treatment which was less when compared to other 
protected treatment namely CM-202 $(8.2 \%)$. In inoculated treatment least disease severity of 76.8 per cent was observed in the variety
CM-202. The ' $t$ ' value was significant in both the varieties namely CM-202 (7.4\%) and CM-219 J (9.8\%).

Table.1 Yield loss due to turcicum leaf blight severity in two susceptible maize varieties

\begin{tabular}{|c|c|c|c|c|c|c|}
\hline Varieties & Treatments & $\begin{array}{c}\text { Disease } \\
\text { severity } \\
(\%)\end{array}$ & $\begin{array}{c}\text { t-value } \\
\text { observed }\end{array}$ & $\begin{array}{c}\text { Grain } \\
\text { yield } \\
\text { (Kg/ha) }\end{array}$ & $\begin{array}{c}\text { Grain } \\
\text { yield loss } \\
(\%)\end{array}$ & $\begin{array}{c}\text { t-value } \\
\text { observed }\end{array}$ \\
\hline \multirow{2}{*}{ CM-202 } & Inoculated & 76.8 & \multirow{2}{*}{$7.4^{*}$} & 4614.2 & \multirow{2}{*}{30.94} & \multirow{2}{*}{$4.5^{*}$} \\
\hline & Protected & 8.2 & & 8360.7 & & \\
\hline \multirow{2}{*}{ CM-219 J } & Inoculated & 89.4 & \multirow{2}{*}{$9.8 *$} & 3219.6 & \multirow{2}{*}{37.64} & \multirow{2}{*}{$4.1^{*}$} \\
\hline & Protected & 6.5 & & 8123.2 & & \\
\hline
\end{tabular}

@ computed according to the method of Cramer (1967)

*significant@ $5 \%$

The yield obtained in the inoculated and protected plots of two varieties at 15 per cent moisture levels was recorded. Data on grain yield obtained $(\mathrm{Kg} / \mathrm{ha})$ was calculated using paired ' $t$ ' test and the yield losses recorded were compared. Both the varieties, CM-202 (8.2 \%) and CM-219 J (6.5\%) showed significant response to disease severity.

Among two varieties Cm-202 showed highest yield in protected plot $(8360.7 \mathrm{Kg} / \mathrm{ha})$ and less in inoculated plot $(4614.2 \mathrm{Kg} / \mathrm{ha})$ followed by CM-219 J grain yield of 8123.2 $\mathrm{Kg} / \mathrm{ha}$ in protected plot and $3219.6 \mathrm{Kg} / \mathrm{ha}$ in inoculated plot (Table 1). Among two varieties, the maximum grain yield loss was notice in CM-219 J (37.64 \%) compared to CM-202 (30.94 \%) where the grain yield loss was less. The extent of grain yield loss due to turcicum leaf blight in present study varies from 30.94 to 37.64 per cent in two susceptible varieties.

Comparative grain yield assessment between controlled and inoculated conditions revealed more than 50 per cent loss under high disease pressure. Northern corn leaf blight reduced the yield of susceptible single crosses from 40 to 68 per cent (Ullstrup, 1951). Chenulu and Hora (1962) observed that the loss in grain yield varied from 27.6 to 90.7 per cent. Loss in grain yield ranging from 16.7 to 62.3 per cent depending on disease severity levels (Raymundo and Hooker, 1981). Pandurange Gowda et al., (1992) observed the maximum grain yield loss was 45.7 per cent. Bunker and Mathur (2006) noticed 20 to 30 per cent reduction in grain yield. The present findings are in accordance with the findings of earlier workers and clearly indicate that, as the disease severity increases, the loss in grain yield was more upto 30 to 38 per cent.

\section{References}

Brewbaker, J. L., Logrono, M. L. and Kim, S. K., 1990. The MIR (maize inbred resistance) trials. Performance of tropical-adapted maize inbreds, pp 1-26, Bulletin Research series 62, Hawaii Institute of Tropical Agriculture and Human Resources, University of Hawaii, Manao, Hawaii.

Bunker, R. N., and Mathur, K., 2006. Assessment of losses in sorghum caused by leaf blight (Exserohilum turcicum). J. Mycol. Pl. Pathol., 36(1): 71-73.

Cardwell, K. F., Schulthess, F., Ndemah, R. and Ngoko, Z., 1997. A systems approach to assess crop health and maize yield losses due to pests and diseases in Cameroon. Agric. Ecosyst. 
Environ, 65:33-47.

Chenulu, H. H., and Hora, T. S., 1962. Studies on losses due to Helimnthosporium blight of maize. Indian Phytopath, 15:235.

Cramer, H. H., 1967. Plant protection and world crop production. Bayer, Leverkusen, West Germany, pp 1-54.

Pandurange Gowda, K. T., Shekar Shetty, H., Jayarama Gowda, B., Prakash, H. S. and Sangam Lal, 1992. Comparison of two methods for assessment of yield loss due to turcicum leaf blight of maize. Indian Phytopath, 45(3): 316-320.
Raymundo, A. D., and Hooker, A. L., 1981. Measuring the relationship between northern corn leaf blight and yield losses. Plant Dis., 65: 325-337.

Ullstrup, A. J., 1951. The effect of some leaf disease on grain yield in corn. Phytopathology, 41: 34-36.

Yashitola, D., 2003. Cloning and characterization of xylanase genes from phytopathogenic fungi with a special reference to Helminthosporium turcicum, the cause of northern leaf blight of maize. Academic thesis, University of Helsinki, Finland.

\section{How to cite this article:}

Shankara, K., R.S. Pradhan and Patole, S.P. 2017. Yield Loss Assessment due to Turcicum Leaf Blight of Maize Caused by Exserohilum turcicum. Int.J.Curr.Microbiol.App.Sci. 6(10): 2888-2891. doi: https://doi.org/10.20546/ijcmas.2017.610.340 